\title{
ЭНДОКРИННЫЕ ЗАБОЛЕВАНИЯ И НОВАЯ КОРОНОВИРУСНАЯ ИНФЕКЦИЯ У ПАЦИЕНТОВ ДО 18 ЛЕТ. ПЕРВЫЕ РЕЗУЛЬТАТЫ
}

\author{
1,3Петряйкина Е.Е., 1,3Ртищев А.Ю., ${ }^{1}$ Глазырина А.А., ${ }^{3}$ Путилина Е.А., \\ ${ }^{1}$ Рыбкина И.Г., ${ }^{1,3}$ Воронцова И.Г., ${ }^{1,2}$ Тихонович Ю.В., ${ }^{3}$ Парфенова Е.А., ${ }^{3}$ Путилина Е.А., \\ ${ }^{3}$ Прометной Д.В., ${ }^{3}$ Куличенко Т.В.
}

${ }^{1}$ ГБУЗ «Морозовская детская городская клиническая больница Департамента здравоохранения города Москвы», г. Москва

${ }^{2}$ ФГАОУ ВО «Первый Московский государственный медицинский университет им. И.М. Сеченова (Сеченовский университет)», г. Москва

${ }^{3}$ ФГАОУ ВО «Российский национальный исследовательский медицинский университет имени Н.И. Пирогова», г. Москва

Введение. Новый коронавирус 2019 г. (SARS-CoV-2) вызвал пандемию инфекции, названной COVID-19. К концу 2020 г. общее число зарегистрированных случаев заболевания во всем мире превысило 79 млн. человек, более 1,7 млн. человек умерли. С марта 2020 г. появились данные о новом заболевании у детей на фоне COVID-19, получившим в отечественной литературе название «детский мультисистемный воспалительный синдром» (ДМВС), характеризующимся выраженным гипервоспалительным ответом и являющимся аналогом «цитокинового шторма» у взрослых пациентов. ДМВС обычно развивается через 1-6 недель после перенесенной COVID-19 и, согласно критериям CDC (США), характеризуется наличием фебрильной лихорадки более 24 часов, резким нарастанием маркеров воспаления (повышение уровня нейтрофилов, СОЭ, С-реактивного белка, СРБ, прокальцитонина, ПКТ, ферритина, лактатдегидрогеназы, ЛДГ, интерлейкина-6, ИЛ-6), нарушением коагуляции с повышением уровня фибриногена и D-димера, мультиорганной недостаточностью, положительными маркерами COVID-19 или высокой вероятностью контакта с инфицированными пациентами. ДМВC, ассоциированный с COVID-19, приводит к опасным для жизни кардиоваскулярным осложнениям, требующим интенсивной терапии, а вероятными предрасполагающими факторами к данному синдрому являются такие коморбидные заболевания как избыточная масса тела и ожирение, бронхиальная астма, неврологические заболевания, системная красная волчанка, сахарный диабет. В зарубежной литературе описан единственный случай ДМВС у пациентки 8 лет с впервые выявленным сахарным диабетом 1 типа (ВВСД1). В отечественной литературе впервые описан клинический случай ДМВС у пациентки с тяжелым декомпенсированным диабетическим кетоацидозом (ДКА) на фоне манифестации СД1 (Ю.В. Тихонович с соавт., Педиатрия им. Г.Н. Сперанского, 2021; 100 (2): 295-300).

Материалы и методы. Проанализированы данные по Москве: на 1.01.2021 г. количество детей и подростков с сахарным диабетом (СД) всех типов, с ожирением, находящихся на диспансерном учете в поликлиниках ДЗМ. Всего 4351 пациент с СД; всего 12626 пациентов с ожирением. Перенесли подтвержденную новую коронавирусную инфекцию в 2020 г. пациенты с СД - 248 (5,6\%); с ожирением - 845 (7\%) от общей численности профильных пациентов. Из числа заболевших, тяжесть течения заболевания которых потребовала госпитализации: СД - 18 (7,2 \% заболевших); ожирение - 11 (1,3\% заболевших). Летальных исходов не было. Вместе пациентов до 18 лет с ожирением и СД в Москве за 2020 г. в связи с тяжестью течения новой коронавирусной инфекции госпитализировано из $1093-29$ человек $(2,7 \%)$.

Результаты и их обсуждение. По публикациям ДЗМ по тяжести дети и подростки до 18 лет в связи с верифицированной новой коронавирусной инфекцией госпитализировались в 7,6\% случаях от всех заболевших в московской популяции до 18 лет. Таким образом, процент тяжелого течения новой 
коронавирусной инфекции у пациентов до 18 лет с СД, независимо от типа, соответствует общемировым данным, при том, что в общемосковской статистике профильной госпитализации были и пациенты с онкологическими, неврологическими и другими нарушениями.

С марта 2020 г. в Российской детской клинической больнице ФГАОУ ВО РНИМУ им. Н.И. Пирогова по приказу Минздрава РФ начал работу по заявкам регионов Федеральный детский реанимационный консультативный центр (ФДРКЦ) для пациентов с COVID-19 и пневмониями. По данным ФДРКЦ на 1.04.2021 г. (проконсультированные по российским регионам пациенты) летальности и пребыванию в ОРИТ, погибло 52 ребенка (9,2\%), из которых 90,4\% (48 из 52) составляли дети с коморбидной патологией, среди которых на 4 месте после органического поражения центральной нервной системы, врожденных пороков сердца, онкопатологии, - 7,7\% (4/52), имели СД1. Можно предположить, с учетом данных ФДРКЦ, что у ребенка с СД риск развития тяжести новой коронавирусной инфекции до необходимости госпитализации в ОРИТ небольшой, соответствует популяционному, но при развитии тяжелого течения до требующего оказания медицинской помощи в ОРИТ, риск летального исхода повышается до $15 \%$.

Заключение: представленные данные демонстрируют необходимость обсуждения программ вакцинопрофилактики с инициацией профильных клинических исследований, возможно, с включением выделенных групп риска по тяжелому течению новой короновирусной инфекции среди пациентов до 18 лет, страдающих хроническими заболеваниями, с учетом международного и отечественного опыта. 